\title{
The rise and fall of methanotrophy following a deepwater oil-well blowout
}

\author{
M. Crespo-Medina', C. D. Meile ${ }^{1}$, K. S. Hunter ${ }^{1}$, A-R. Diercks ${ }^{2}$, V. L. Asper ${ }^{3}$, V. J. Orphan ${ }^{4}$, \\ P. L. Tavormina ${ }^{4}$, L. M. Nigro ${ }^{\text {5 }}$, J. J. Battles ${ }^{1}$, J. P. Chanton ${ }^{6}$, A. M. Shiller ${ }^{3}$, D-J. Joung ${ }^{3}$, \\ R. M. W. Amon ${ }^{7}$, A. Bracco ${ }^{8}$, J. P. Montoya ${ }^{9}$, T. A. Villareal ${ }^{10}$, A. M. Wood ${ }^{11}$ and S. B. Joye ${ }^{1 \star}$
}

The blowout of the Macondo oil well in the Gulf of Mexico in April 2010 injected up to $\mathbf{5 0 0 , 0 0 0}$ tonnes of natural gas, mainly methane, into the deep sea'. Most of the methane released was thought to have been consumed by marine microbes between July and August $2010^{2,3}$. Here, we report spatially extensive measurements of methane concentrations and oxidation rates in the nine months following the spill. We show that although gas-rich deepwater plumes were a short-lived feature, water column concentrations of methane remained above background levels throughout the rest of the year. Rates of microbial methane oxidation peaked in the deepwater plumes in May and early June, coincident with a rapid rise in the abundance of known and new methane-oxidizing microbes. At this time, rates of methane oxidation reached up to $5,900 \mathrm{nmol}^{1}{ }^{1} \mathrm{~d}^{1}$-the highest rates documented in the global pelagic ocean before the blowout ${ }^{4}$. Rates of methane oxidation fell to less than $50 \mathrm{nmol}^{1}{ }^{1} \mathrm{~d}^{\mathbf{1}}$ in late June, and continued to decline throughout the remainder of the year. We suggest the precipitous drop in methane consumption in late June, despite the persistence of methane in the water column, underscores the important role that physiological and environmental factors play in constraining the activity of methane-oxidizing bacteria in the Gulf of Mexico.

A seafloor oil-well blowout and subsequent sinking of the Deepwater Horizon drilling rig in the Gulf of Mexico on 20 April 2010 initiated an unprecedented discharge of oil and gaseous hydrocarbons into the deep ocean. We conducted a nine-month sampling campaign (5 May-3 December 2010; Supplementary Fig. 1 and Supplementary Table) to document the fate and dynamics of methane in the system. Direct measurements of methane concentrations, microbially mediated aerobic methaneoxidation rates (for example, methanotrophy) and particulate methane monooxygenase gene abundance and diversity were made. Concentrations of inorganic nutrients and dissolved iron and copper were also quantified to explore the factors potentially regulating methanotrophic activity. Our detailed biogeochemical and molecular measurements acquired over a large geographic area ( $>105,000 \mathrm{~km}^{2}$ ) suggest that, following the blowout, environmental or physiological factors ultimately limited methanotrophic abundance and activity, rather than availability of methane, oxygen, or higher hydrocarbon priming as previously reported ${ }^{1,2,5}$. The observed reduction in rates of methanotrophy after the end of June suggests that methanotrophs did not consume all of the discharged methane.

Time series sampling revealed clear spatiotemporal variations in dissolved alkane distribution. From May to early June, concentrations of dissolved alkanes, from methane to pentane $e^{1,5}$, were enriched between 900 and 1,300 m water depth southwest of the wellhead (Fig. 1a); however, focused deepwater plumes were not apparent after that time (Supplementary Fig. 2). Previous studies reported these gas-rich, deepwater plumes from snapshot samples taken in May and June $e^{1,5,6}$; the time series data presented here show that the gases were subsequently dispersed (Supplementary Fig. 2), distributing Macondo methane with a distinct carbon isotopic signature of $-57.4 \% 0 \pm 0.4 \%$ o $(n=27)$ throughout the water column by late June 2010. At that time, Macondo methane $\left(1.7 \mu \mathrm{M}\right.$; identified by its isotopic signature of $\delta^{13} \mathrm{C}-\mathrm{CH}_{4}$ of $-53.8 \pm 1.5 \%, n=5$; see further discussion in Supplementary Methods), was observed at a depth of $600 \mathrm{~m}$ at Mississippi Canyon MC118, a natural seep ten miles north of Macondo that releases thermogenic methane $\left(\delta^{13} \mathrm{C}-\mathrm{CH}_{4}\right.$ of $-45 \%$; ref. 7). By July, $\mathrm{C}_{2}-\mathrm{C}_{5}$ concentrations were below detection even though methaneenriched waters extended from 600 to $1,300 \mathrm{~m}$ (Supplementary Fig. 3). In August/September, methane concentrations remained elevated throughout the water column at sites north of the Macondo wellhead (for example, a $100 \mathrm{nM}$ methane anomaly was observed at MC118 at $650 \mathrm{~m}$ in September 2010) but not to the south/southwest, where we observed low concentrations and low turnover rates of methane at plume depths (900-1,300 m), consistent with previously reported observations ${ }^{2}$.

The observed redistribution of methane through the water column within two months may reflect diapycnal mixing amplified by ageostrophic internal waves whose presence is ensured by the eddy activity and bathymetric conditions typical of the region around the Macondo wellhead ${ }^{8,9}$. Rapid plume dispersion may have also resulted from the ascent of buoyant, probably oil-saturated hydrate flakes ${ }^{1}$. As $\mathrm{C}_{2}$ and $\mathrm{C}_{3}$ gases are preferentially concentrated into structure II gas hydrate ${ }^{10}$ relative to their abundance in the venting gas, hydrate formation and dissociation could abiotically alter the relative abundance of alkanes in solution ${ }^{1}$ thereby

\footnotetext{
${ }^{1}$ Department of Marine Sciences, University of Georgia, Athens, Georgia 30602, USA, ${ }^{2}$ National Institute of Underwater Science and Technology, University of Southern Mississippi, Abbeville, Mississippi 38601, USA, ${ }^{3}$ Department of Marine Science, University of Southern Mississippi, Stennis Space Center, Mississippi 39529, USA, ${ }^{4}$ Division of Geological and Planetary Sciences, California Institute of Technology, Pasadena, California 91125, USA, ${ }^{5}$ Department of Marine Sciences, University of North Carolina, Chapel Hill, North Carolina 27599, USA, ${ }^{6}$ Department of Earth, Ocean, and Atmospheric Sciences, Florida State University, Tallahassee, Florida 32306, USA, ${ }^{7}$ Department of Marine Sciences, Texas A\&M University, Galveston, Texas 77551, USA, ${ }^{8}$ School of Earth and Atmospheric Sciences, Georgia Institute of Technology, Atlanta, Georgia 30332, USA, ${ }^{9}$ School of Biology, Georgia Institute of Technology, Atlanta, Georgia 30332, USA, ${ }^{10}$ Marine Sciences Institute, The University of Texas-Austin, Port Aransas, Texas 78373, USA, ${ }^{11}$ NOAA Atlantic Oceanographic and Meteorological Laboratory, Miami, Florida 33149, USA. *e-mail: mjoye@uga.edu
} 


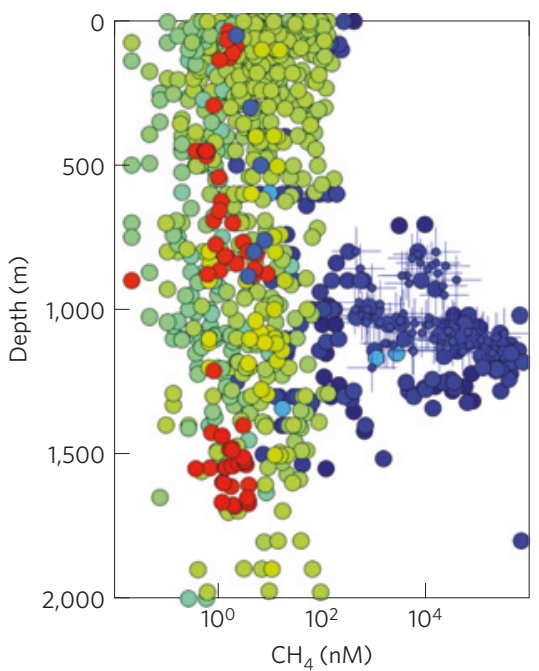

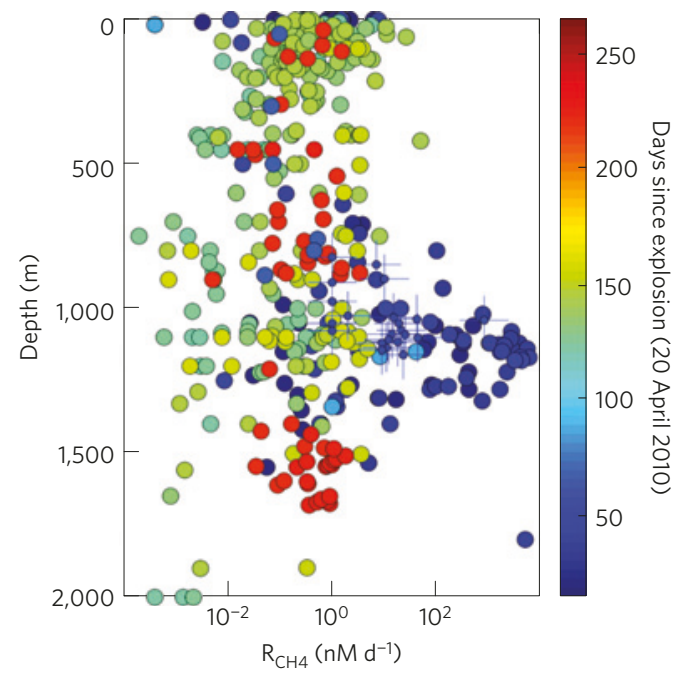

Figure 1 | Methane dynamics following the Deepwater Horizon discharge. a, Methane concentration data and $\mathbf{b}$, methane-oxidation rates between 5 May and 2 December 2010. Data from ref. 5 are shown as crosses (colour coding is the same).

a

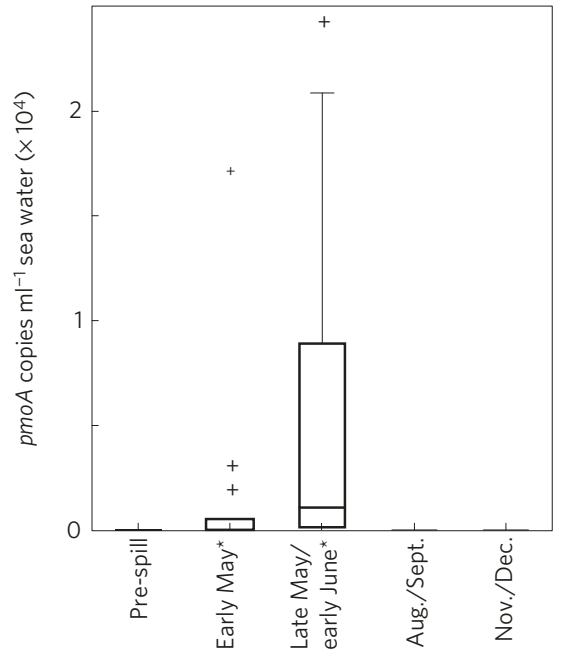

b

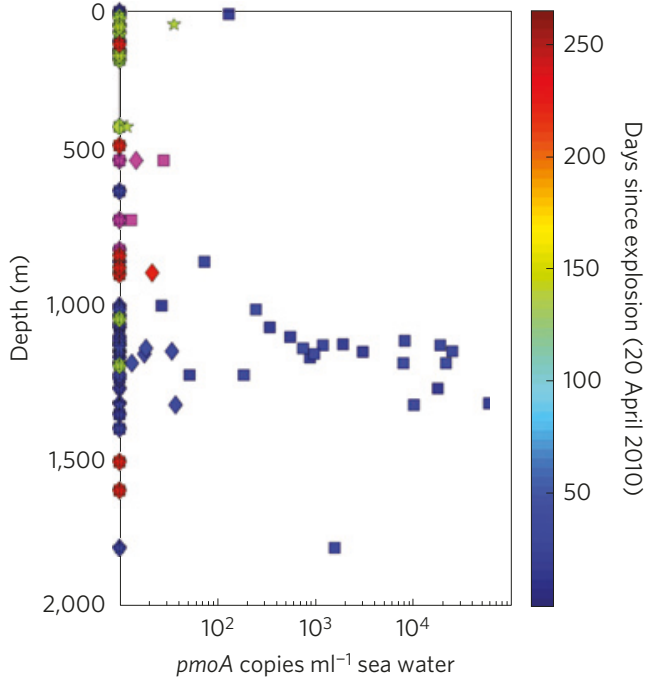

Figure 2 | Abundance of pmoA genes following the Deepwater Horizon discharge. a, Abundance of methanotrophic bacterial pmoA genes, data are binned by time period. b, Abundance of pmoA gene copies over time (same colour coding as Fig. 1; pre-spill samples are magenta). Stars, OPU1; diamonds, OPU3; squares, new phylotype. Data in the two time periods marked with an asterisk in a are different from those collected at other times with a statistical significance of $P<0.05$. Plus signs denote extreme data outliers.

complicating the use of $\mathrm{C}_{1} / \mathrm{C}_{2}$ and $\mathrm{C}_{1} / \mathrm{C}_{3}$ ratios as indicators of microbial consumption ${ }^{5}$.

The increase in methane concentration rapidly stimulated biological methane oxidation (methanotrophy), which later became constrained by physiological or environmental factors. In early May 2010, 11 days after the discharge began, methane-oxidation rates ranged from 0.014 to $502 \mathrm{nmoll}^{-1} \mathrm{~d}^{-1}$ (hereafter $\mathrm{nM} \mathrm{d}^{-1}$ ) and were highest in the deepwater plumes (Fig. 1b) where the methane turnover time was $\sim 400$ days. Methane-oxidation rates increased through late May/early June, reaching maximal rates of $5,900 \mathrm{nM} \mathrm{d}^{-1}$ that, if sustained, lowered the methane pool turnover time to roughly two months. These high rates exceed those previously reported in the Gulf by four orders of magnitude ${ }^{5,11}$, are the highest reported for the pelagic ocean ${ }^{4,12}$ and are among the highest documented in aquatic ecosystems, including wetlands ${ }^{13}$. Methanotrophic activity dropped to tens to hundreds of $\mathrm{nM} \mathrm{d}^{-1}$ in late June $\mathrm{e}^{5}$, despite methane concentrations well above background (tens of $\mu \mathrm{M}$, with a maximum of $180 \mu \mathrm{M}$; Fig. 1) and continued to drop slowly between July and December to $3-5 \mathrm{nM} \mathrm{d}^{-1}$. Though much lower than those observed in May, these rates were significantly above background rates, which ranged from 0.0001 to $0.1 \mathrm{nM} \mathrm{d}^{-1}$ (ref. 11).

Characterized gammaproteobacterial methanotrophs prefer high methane concentrations and typically exhibit high maximal rates of activity $^{14}$. Quantitative polymerase chain reaction (qPCR) targeting the $p m o A$ gene of two cosmopolitan gammaproteobacterial marine methanotrophs ${ }^{15}$ and a sequence-divergent $p m o A$ identified during the time series revealed the response of these three putative methane-oxidizing lineages to the gas injection. Overall, $p m o A$ gene abundance was substantially higher in May/June compared with prespill conditions (Fig. 2a), consistent with increases in methaneoxidation rate (Fig. 1b). The change in $p m o A$ gene abundance was dominated by an ingrowth of a rare (tens of copies per millilitre in prespill samples), sequence-divergent $p m o A$ variant whose abundance increased 200 -fold by late May (Fig. 2b). By 


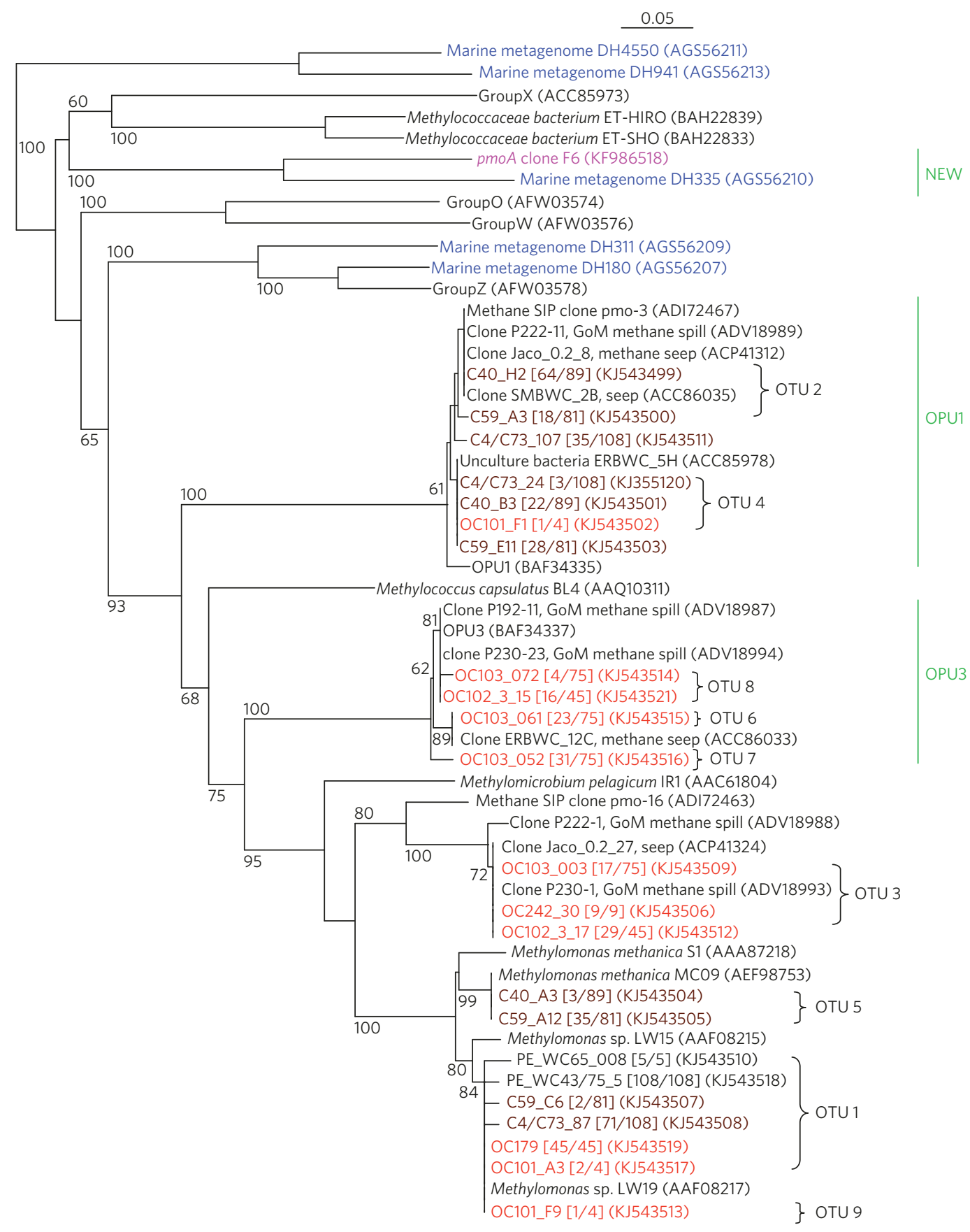

Figure 3 | Diversity of microbial pmoA genes between March and December 2010. Phylogenetic analysis of the inferred amino acid sequences encoded by the pmoA gene. The neighbour-joining tree was constructed using PHYLO_WIN. Sequences from this study are colour coded: black, RV Pelican, early May 2010; brown, RV Walton Smith, late May-early June 2010; red, RV Oceanus, August-September 2010. Known microbial species are denoted by italics. Green bars indicate groups targeted by the pmoA qPCR, including the novel pmoA sequence, KF986518 (magenta). Sequences in blue are from ref. 17 metatranscriptome. Numbers in brackets represent the number of clones represented by each sequence as a fraction of the total clones from each sample. Bootstrap values higher than $50 \%$ are indicated. Scale bar indicates $5 \%$ estimated substitutions.

August/September the median $p m o A$ gene abundance was similar to background levels (Fig. 2).

The peak in abundance of the $p m o A$ genes (Fig. 2) in May and early June corresponded to maximal methane-oxidation rates (Fig. 1b), indicating that the methanotrophy response to methane injection occurred on a time scale of days to weeks rather than months as suggested previously ${ }^{2,3,5}$. The measured increase in activity requires an increase in cell specific rates ${ }^{16}$ and/or ingrowth of a subpopulation with radically different kinetics. An ingrowth of new methanotrophs is supported by the observed increase in sequence-divergent $p m o A$ sequences during May and June (Fig. 2) and by the abundance of transcripts with homology to this new $p m o A$ sequence in the transcriptome of samples collected contemporaneously with our samples during May/June ${ }^{17}$.

Clone library analysis targeting canonical $p m o A$ sequences sheds additional light on the dynamics of methanotroph response to the Macondo blowout. Phylogenetic analysis of the inferred amino acid sequence of the $p m o A$ gene from selected samples (Fig. 3 and Supplementary Table 2) indicated that sequences similar to the pmoA gene from several Methylomonas spp. were present 

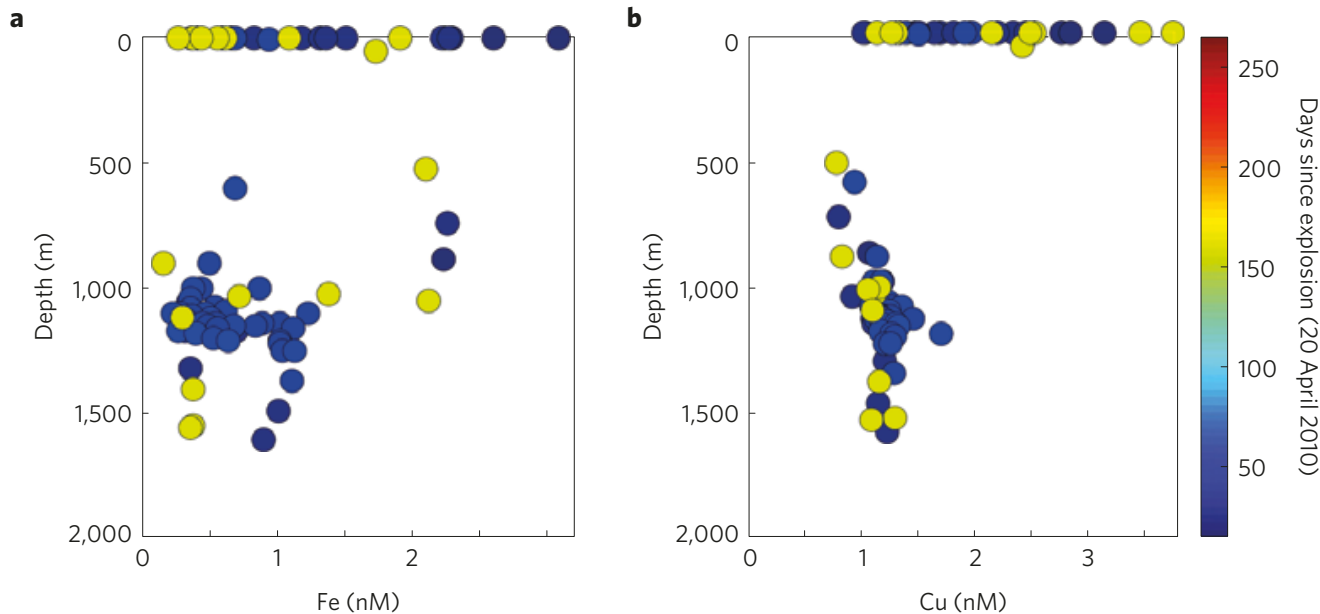

Figure 4 | Concentrations of dissolved trace metals required by methanotrophs. $\mathbf{a}$, Water column concentration of dissolved iron and $\mathbf{b}$, copper in samples collected in May, June and October 2010

throughout the sampling campaign. However, sequences similar to $p m o A$ genes associated with natural marine hydrocarbon seeps off the coast of Costa Rica (P.L.T. and V.J.O., unpublished observations) and off the coast of California ${ }^{18}$, and to sequences identified months after the spill started ${ }^{2}$ were detected in samples from May/June and August/September (Fig. 3). Transcripts related to these new $p m o A$ sequences were identified in May/June samples ${ }^{17}$ parallel to our rate and molecular samples. Together, these data show that the activity and response of both canonical and phylogenetically divergent methanotrophs to the methane injection was essentially instantaneous. However, the specific metabolic capabilities of the new phylotype is not known; it could be capable of oxidizing methane and higher alkanes (for example, propane), which, in light of the high abundance of $\mathrm{C}_{1}-\mathrm{C}_{5}$ alkanes, could provide it with a metabolic advantage.

The sudden decrease in methanotrophic activity during June/July, in the presence of sufficient primary substrates- $-\mathrm{O}_{2}$ and $\mathrm{CH}_{4}$-suggests physiological or environmental limitations such as kinetic selection of the methanotroph population, trophic interactions or mortality (for example, viral lysis, selective grazing pressure), nutrient limitation, or trace metal limitation. The observed increase of predominantly gammaproteobacterial (Type I) methanotrophs, as documented by the pmoA libraries (Fig. 3) and metatranscriptomic analysis ${ }^{17}$, in response to the extraordinarily high methane concentration in pelagic ocean waters agrees with previous results ${ }^{14}$ from soils, where gammaproteobacterial (Type I) methanotrophs with a low affinity for methane and high maximal oxidation rates responded rapidly to methane amendment. Following the blowout, the highly active population persisted only briefly, as evidenced by the transient increase in sequence-divergent $p m o A$ gene abundances during the first six weeks of the discharge (Fig. 2). As the gas-rich plumes dispersed, we surmise that methane concentrations dropped to levels below those accessible to these new methanotrophs, resulting in a notable decrease in methane-oxidation rates and, subsequently, a decrease in $p m o A$ gene abundance.

Additional factors may have contributed to the decline in methane-oxidation rates and prevented other components of the methanotroph population from increasing their activity during later phases of the event. Though not documented in the ocean, selective grazing of methanotrophs by protists in soils ${ }^{19}$ and zooplankton in lakes ${ }^{20}$ can regulate their abundance and activity. Similarly, viral infection and targeted mortality are known to affect microbial community composition ${ }^{21}$ and-in combination with grazingmay have impacted methanotroph abundance and activity ${ }^{21}$ and contributed to the observed rapid decrease in abundance and oxidation rates. It is less likely that the availability of the main nutrients, nitrogen and phosphorus, which were present in sufficiently high concentrations (Supplementary Fig. 4), limited methanotrophic activity or the recovery of methanotrophs after the observed drop in rates. Particulate methane monooxygenase, the enzyme encoded by pmo, has a high demand for both copper and iron ${ }^{22-24}$. Dissolved $(<0.45 \mu \mathrm{m})$ iron and copper (Fig. 4) concentrations during early May were in the low $\mathrm{nM}$ range. Within the deepwater plume, Fe $(0.4-1 \mathrm{nM})$ and $\mathrm{Cu}(1.1 \mathrm{nM})$ concentrations were comparable to values observed in the open Atlantic ${ }^{25}$. By late May/early June, dissolved $\mathrm{Fe}$ concentrations exhibited a strong minimum in the deepwater plume (Fig. 4) and were low enough to limit methanotroph activity at high $(\mu \mathrm{M})$ methane concentration ${ }^{26,27}$.

The factors that regulate the fate of hydrocarbons in the ocean owing to sudden, large discharge events are poorly constrained at the microbial level. The response and regulation of microbial activity and microbial community succession, and the impacts of microbial activity at the ecosystem level, including generation of oxygen-depleted waters ${ }^{2,28}$ or microbially mediated carbon transfer within the marine food web, is limited. Our data underscore the key roles of vertical mixing ${ }^{8,9}$ and gas hydrate dynamics ${ }^{1}$ in driving methane distributions following the Macondo blowout. Patterns of methane abundance thus generated unexpected patterns of microbial activity and distributions. The efficient, and faster than previously reported ${ }^{2,3,5}$, response of methanotrophs to the Macondoderived methane injection revealed a surprising capability of the pelagic oceanic microbial community. Rapid microbial community shifts and metabolic flexibility has been observed previously in soils $^{14}$, permafros $\mathrm{t}^{29}$ and nearshore pelagic ${ }^{3}$, microbial communities, but not yet in the deep pelagic ocean. Most surprising, though, was the inability of the methanotroph community to maintain the high levels of activity achieved in late May/early June, because maintaining those observed levels of activity for less than two months would have efficiently consumed the entirety of Macondo-derived methane. Instead, the activity of methanotrophs crashed in late June, which limited consumption of the introduced methane and highlights the complex feedbacks between physics, geochemistry and microbiology that shape and regulate microbial community responses to large-scale perturbations in the open ocean. Such complexities limit our ability to constrain the ultimate fate of Macondo methane in the Gulf ecosystem.

Received 14 January 2014; accepted 4 April 2014; published online 11 May 2014 


\section{References}

1. Joye, S. B., MacDonald, I. R., Leifer, I. \& Asper, V. Magnitude and oxidation potential of hydrocarbon gases released from the BP oil well blowout. Nature Geosci. 4, 160-164 (2011).

2. Kessler, J. D. et al. A persistent oxygen anomaly reveals the fate of spilled methane in the deep Gulf of Mexico. Science 331, 312-315 (2011).

3. Valentine, D. L. et al. Dynamic autoinoculation and the microbial ecology of a deep water hydrocarbon irruption. Proc. Natl Acad. Sci. USA 109, 20286-20291 (2012).

4. De Angelis, M. A., Lilley, M. d., Olson, E. J. \& Baross, J. A. Methane oxidation in deep-sea hydrothermal plumes of the endeavour segment of the Juan de Fuca Ridge. Deep-Sea Res. I 40, 1169-1186 (1993).

5. Valentine, D. L. et al. Propane respiration jump-starts microbial response to a deep oil spill. Science 330, 208-211 (2010).

6. Camilli, R. et al. Tracking hydrocarbon plume transport and biodegradation at Deepwater Horizon. Science 330, 201-204 (2010).

7. Bowles, M. W., Samarkin, V. A., Bowles, K. M. \& Joye, S. B. Weak coupling between sulfate reduction and the anaerobic oxidation of methane in methane-rich seafloor sediments during ex situ incubation. Geochim. Cosmochim. Acta 75, 500-519 (2011).

8. Kunze, E. Near-inertial wave propagation in geostrophic shear. J. Phys. Oceanogr. 15, 544-565 (1985).

9. Polzin, K. L., Toole, J. M., Ledwell, J. R. \& Schmitt, R. W. Spatial variability of turbulent mixing in the Abyssal Ocean. Science 276, 93-96 (1997).

10. Sassen, R. et al. Thermogenic gas hydrates and hydrocarbon gases in complex chemosynthetic communities, Gulf of Mexico continental slope. Org. Geochem. 30, 485-497 (1999).

11. Wankel, S. D. et al. New constraints on methane fluxes and rates of anaerobic methane oxidation in a Gulf of Mexico brine pool via in situ mass spectrometry. Deep-Sea Res. II 57, 2022-2029 (2010).

12. Reeburgh, W. S. Oceanic methane biogeochemistry. Chem. Rev. 107, 486-513 (2007)

13. Segers, R. Methane production and methane consumption: A review of processes underlying wetland methane fluxes. Biogeochemistry 41, 21-51 (1998).

14. Knief, C., Kolb, S., Bodelier, P. L., Lipski, A. \& Dunfield, P. F. The active methanotrophic community in hydromorphic soils changes in response to changing methane concentration. Environ. Microbiol. 8, 321-333 (2006).

15. Tavormina, P. L., Ussler, W. III, Joye, S. B., Harrison, B. K. \& Orphan, V. J. Distributions of putative aerobic methanotrophs in diverse pelagic marine environments. ISME J. 4, 1-11 (2010).

16. Carini, S., Bano, N., LeCleir, G. \& Joye, S. B. Aerobic methane oxidation and methanotroph community composition during seasonal stratification in Mono Lake, California (USA). Environ. Microbiol. 7, 1127-1138 (2005).

17. Rivers, A. R. et al. Transcriptional response of bathypelagic marine bacterioplankton to the Deepwater Horizon oil spill. ISME J. 7, 2315-2329 (2013).

18. Tavormina, P. L., Ussler, W. III \& Orphan, V. J. Planktonic and sediment-associated aerobic methanotrophs in two seep systems along the North American margin. Appl. Environ. Microbiol. 74, 3985-3995 (2008).

19. Murase, J. \& Frenzel, P. Selective grazing of methanotrophs by protozoa in a rice field soil. Fems Microbiol. Ecol. 65, 408-414 (2008).

20. Bastviken, D., Ejlertsson, J., Sundh, I. \& Tranvik, L. Methane as a source of carbon and energy for lake pelagic food webs. Ecology 84, 969-981 (2003).

21. Bouvier, T. \& del Giorgio, P. A. Key role of selective viral-induced mortality in determining marine bacterial community composition. Environ. Microbiol. 9, 287-297 (2007)
22. Balasubramanian, R. et al. Oxidation of methane by a biological dicopper centre. Nature 456, 115-120 (2010).

23. Murrell, J. C., Gilbert, B. \& McDonald, I. R. Molecular biology and regulation of methane monooxygenase. Arch. Microbiol. 173, 325-332 (2000).

24. Takeguchi, M., Ohashi, M. \& Okura, I. Role of iron in particulate methane monooxygenase from Methylosinus trichosporium OB3b. Biometals 12, 123-129 (1999).

25. Bergquist, B. A. \& Boyle, E. A. Dissolved iron in the tropical and subtropical Atlantic Ocean. Glob. Biogeochem. Cycles 20, GB1015 (2006).

26. Berson, O. \& Lidstrom, M. E. Study of copper accumulation by the type I methanotroph Methylomicrobium albus BG8. Env. Sci. Tech. 30, 802-809 (1996).

27. Park, S., Shah, N. N., Taylor, R. T. \& Droege, M. W. Batch cultivation of Methylosinus trichosporium OB3b I: Production of soluble methane monooxygenase. Biotechnol. Bioeng. 38, 423-433 (1991).

28. Joye, S. B., Bowles, M. W., Samarkin, V. A., Hunter, K. S. \& Niemann, H. Biogeochemical signatures and microbial activity of different cold-seep habitats along the Gulf of Mexico deep slope. Deep-Sea Res. II 57, 1990-2001 (2010).

29. Mackelprang, R. et al. Metagenomic analysis of a permafrost microbial community reveals a rapid response to thaw. Nature 480, 368-371 (2011).

30. Sjostedt, J. et al. Recruitment of members from the rare biosphere of marine bacterioplankton communities after an environmental disturbance. Appl. Environ. Microbiol. 78, 1361-1369 (2012).

\section{Acknowledgements}

We thank C. Mann, A. Vossmeyer, J. Slaughter, C. Comerford, L. Potter, V. Samarkin and S. Cummings for assistance at sea and/or in the laboratory; M. Chistoserdova for providing advice on constructing $\mathrm{q} P C R$ primers and for providing pure cultures of methanotrophs; I. MacDonald, T. Treude and M. Chistoserdova provided constructive feedback on a previous version of this manuscript. Finally we thank the science parties and ship's crews of RV Pelican, RV Nancy Foster, RV Walton Smith, RV Oceanus, RV Cape Hatteras, MY Arctic Sunrise and RV Atlantis. This work was supported by the NOAA Award NA07AR4300464 to the National Institute for Undersea Science and Technology (V.L.A., A.R.D. and S.B.J.), the Department of Energy (Gulf of Mexico Gas Hydrate Research Consortium, 07-11-036 to J.P.C.), the National Science Foundation (OCE-1043225 to S.B.J., OCE-0926699 to T.A.V. and OCE-1042934 to A.M.S.), the Gulf of Mexico Research Initiative (ECOGIG (S.B.J., V.L.A., A.B., J.P.C., A.R.D, J.P.M., C.D.M and T.A.V.) and DEEP-C (J.P.C.)) and the Northern Gulf Institute (A.M.S.). Greenpeace and Texas A\&M at Galveston facilitated the Arctic Sunrise expedition. This is ECOGIG contribution \#192 and the data fall under GRIIDC accession number

(R1.x132.134:0057).

\section{Author contributions}

S.B.J., M.C-M., K.S.H, A-R.D., V.L.A., J.P.C, J.P.M., A.M.W, R.M.W.A., A.M.S., D.J.J, A.V. and T.A.V. collected the samples and/or carried out geochemical and microbial activity rate assays; M.C-M., L.M.N, P.T., J.J.B. and V.J.O. conducted the methanotroph gene analyses; S.B.J., C.D.M., M.C-M., P.T. and A.B. contributed to data reduction and analyses; S.B.J. led development of the manuscript; C.D.M., M.C-M., P.L.T. and V.J.O. made significant contributions and critical feedback was provided by the other co-authors.

\section{Additional information}

Supplementary information is available in the online version of the paper. Reprints and permissions information is available online at www.nature.com/reprints. Correspondence and requests for materials should be addressed to S.B.J.

\section{Competing financial interests}

The authors declare no competing financial interests. 


\title{
The rise and fall of methanotrophy following a deepwater oil-well blowout
}

\author{
M. Crespo-Medina, C. D. Meile, K. S. Hunter, A.-R. Diercks, V. L. Asper, V. J. Orphan, P. L. Tavormina, \\ L. M. Nigro, J. J. Battles, J. P. Chanton, A. M. Shiller, D.-J. Joung, R. M. W. Amon, A. Bracco, \\ J. P. Montoya, T. A. Villareal, A. M. Wood, and S. B. Joye
}

7 Study Sites:

8 A total of 1128 water column samples were collected during ten research cruises to the

9 Gulf of Mexico spanning March (the background sampling cruise) through December

102010 , on board of the R/V Pelican: $1^{\text {st }}$ Mar. $2010-7$ Mar. 2010, $5^{\text {th }}$ May $2010-15$ May

112010 and $20^{\text {th }}$ June $2010-26$ June 2010; R/V F.G. Walton Smith: $25^{\text {th }}$ May $2010-6$

12 June 2010; R/V Nancy Foster: 30 June 2010 - 18 July 2010; R/V Oceanus and R/V Cape

13 Hatteras: $21^{\text {st }}$ Aug. $2010-16$ Sept. 2010; R/V Arctic Sunrise: $20^{\text {th }}$ Sept. $2010-28$ Sept

14 2010; and R/V Atlantis: $8^{\text {th }}$ Nov. $2010-3^{\text {rd }}$ Dec. 2010 (See On-Line Supplementary

15 Table). The pre-spill samples were collected from above a fracture zone at a natural

16 hydrocarbon seep, Mississippi Canyon block 118, in March 2010, roughly a month

17 before the Macondo Blowout began. It is important to note that the pre-spill data does not

18 reflect the microbial abundance of an inactive site that lacks natural seepage inputs rather

19 the data reflects a site impacted by low rates of natural seepage.

Sample collection:

A CTD-Niskin rosette system was used to obtain hydrographic profiles throughout the water column. Niskin bottles were triggered at specific depths and upon return to the surface, each bottle was individual samples were collected for dissolved gas 
25 concentration determination, rates of aerobic methane oxidation, nutrient and metal

26 concentration determination, and microbial molecular analysis (see below).

\section{Methane concentration:}

29 Samples for dissolved alkane quantification were collected as soon as the CTD rosette

30 was secured on deck, as described previously by Joye et al. ${ }^{31}$ with some modifications

31 between cruises. Concentration of $\mathrm{C}_{1}$ to $\mathrm{C}_{5}$ alkanes were determined using headspace

32 extraction (May through

33 or a modified sonication/vacuum extraction technique (August through December) ${ }^{32}$,

34 followed by gas chromatography. A sub-sample ( 0.25 to $1 \mathrm{~mL})$ gas sample was injected

35 into a gas chromatograph (model 8610C, SRI, California) equipped with a flame

36 ionization detector ${ }^{31}$. A temperature ramp was employed to elute $\mathrm{C}_{3+}$ alkanes.

37 Concentrations were calculated by comparison to a certified mixed alkane standard $\left(\mathrm{C}_{1}\right.$ to

$38 \mathrm{C}_{5}$, including both $n$ - and $\left.i-\mathrm{C}_{4}\right)\left(\right.$ Scott Specialty Gases $\left.{ }^{\circledR}\right)$.

40 Aerobic methane oxidation rates:

41 Water column aerobic methane oxidation rates were measured using a tritiated $\left({ }^{3} \mathrm{H}\right) \mathrm{CH}_{4}$

42 radiotracer technique ${ }^{33,34}$. Reactions were done in triplicates in gas-tight glass vials. A

$43 \quad 100 \mu 1$ aliquot of the $\mathrm{C}^{3} \mathrm{H}_{4}$ tracer solution was injected into each replicate yielding a tracer

44 activity of $2 \mathrm{kBq}$. Killed controls were achieved by treating a sample with $3.7 \%$

45 formaldehyde, to arrest microbial activity, prior to tracer addition. The samples were

46 incubated at in situ temperature for 48 to 72 hours; linearity of activity was confirmed by

47 time series. Reactions were terminated by adding $20 \%$ (vol:vol) of pure ethanol to each 
48 vial. Labeled $\mathrm{C}^{3} \mathrm{H}_{4}$ was removed by purging the sample with hydrated air for at least 25

49 minutes. Scintillation cocktail (ScintiSafe $\mathrm{Gel}^{\circledR}$ ) was then added to an aliquot of the

50 sample and ${ }^{3} \mathrm{H}_{2} \mathrm{O}$ produced was quantified using a Beckman 6500 liquid scintillation

51 counter.

52

53 Methane stable carbon isotopic signature:

54 Water samples for methane stable carbon isotopic $\left(\delta^{13} \mathrm{C}\right)$ analyses (May and July) were

55 collected into $125 \mathrm{~mL}$ serum vials. A headspace sub-sample from each vial was injected

56 into a Finnegan Mat Delta V Isotope Ratio Mass Spectrometer coupled to a Hewlet

57 Packard gas chromatograph with a poraplot capillary column. Samples were cryo-

58 focused as described in Chanton and Liptay $(2000)^{35}$, and reported relative to Vienna Pee

59 Dee Belemnite (VPDB) standard.

60

61 Nutrients/Biogeochemistry:

62 Fixation and analysis of water samples for quantifying dissolved ammonium $\left(\mathrm{NH}_{4}{ }^{+}\right)$,

63 inorganic carbon $\left(\mathrm{DIC}\right.$ or $\left.\mathrm{HCO}_{3}{ }^{-}\right)$, nitrate plus nitrite $\left(\mathrm{NO}_{\mathrm{x}}{ }^{-}\right)$, and phosphate $\left(\mathrm{PO}_{4}{ }^{3-}\right)$

64 followed previously described methods ${ }^{36}$. Samples for dissolved trace elements were

65 collected using trace element cleaned, rosette-mounted, teflon-coated, external spring

66 Niskin and Go-Flo bottles. Samples were cleanly syringe-filtered ${ }^{37}$. Metals were isolated

67 from a small volume (3 mL) of sample using Mg-induced co-precipitation with added

68 enriched ${ }^{57} \mathrm{Fe}$ and ${ }^{65} \mathrm{Cu}^{38}$ and then analyzed using isotope-dilution by sector-field

69 inductively coupled plasma-mass spectrometry.

70 
DNA extraction:

72 Water samples for DNA extraction were filtered through a $0.22 \mu \mathrm{m}$ Sterivex filter

73 (Millipore) and stored frozen until extraction. The filter was extracted using the Ultra

74 Clean Soil DNA extraction kit (Mo Bio Laboratories, Inc., Carlsbad, CA) following the

75 manufacturer's instructions with few modifications. Two samples used for $p m o A$ clone

76 libraries (see section below) were extracted using different phenol:chloroform DNA

77 extractions protcols; sample C40-6 was extracted following Vetriani et al. (1999) ${ }^{39}$ while

78 sample C59-9 was extracted according to Adams et al. (2013) ${ }^{40}$. Similar results from

79 ртоA clone libraries were obtained, regardless of the extraction method used, see Fig. 3.

80

81 qPCR amplification:

82 Amplification of Type I relatives OPU1 and OPU3 was achieved with primer set

83 putative_16S_OPU1F (5'-CAATGCCGCGTGTGTGAA-3') and putative_16S_OPU1R

84 (5'-CCTCTCTTCCCCCGACTGAA-3') for OPU1, and primer set putative_OPU3F (5'-

85 AGCACTTTCAATTGGGAGGAAA-3') and putative_OPU3R (5'

86 GCCGGTGCTTCTTCTAAAGGT-3') for $\mathrm{OPU}^{41}{ }^{41}$. The unusual pmoA sequences were

87 originally detected using monooxygenenase intergenic spacer analysis (hereafter,

88 MISA $)^{42}$ and full length $p m o A$ sequences were recovered subsequently following the

89 strategy reported in Tavormina $2013^{42}$. The MISA assay was validated on cultured strains

90 as reported in Tavormina et al. ${ }^{42}$. qPCR primers were developed from the full length

91 sequence using Primer3 software http://frodo.wi.mit.edu/primer3/.

92 
93 On linearized, $\mathrm{CsCl}$-purified plasmid templates, these primer pairs demonstrate $>95 \%$

94 amplification efficiency (as measured over 5 orders of magnitude template

95 concentrations). Cross reactivity between target plasmid templates is $<1 \%$, however these

96 primers may amplify related sequences in complex environmental samples. Quantitative

97 PCR reactions were performed in a StepOne Real Time PCR System (Applied

98 Biosystem), in a reaction consisting of $12.5 \mu$ l of Power SYBR ${ }^{\circledR}$ Green PCR Master Mix,

$991 \mu 1$ of template DNA (1-6 ng/ $\mu 1), 0.625 \mu 1$ of BSA $(10 \mathrm{ng} / \mu 1), 1.25 \mu 1$ of each primer

$100(0.5 \mu \mathrm{M}$ final concentration), and water to a final volume of $25 \mu \mathrm{l}$. qPCR programs

101 consisted in a $95^{\circ} \mathrm{C}$ initial denaturation for $10 \mathrm{~min}$, followed by 40 cycles of $95^{\circ} \mathrm{C}$ for 15

$102 \mathrm{sec}$ and a one step annealing/extension of $1 \mathrm{~min}$ at $57^{\circ} \mathrm{C}$ for Type I methanotrophs $16 \mathrm{~S}$

103 rRNA gene, as well as for OPU1 and OPU3, or $1 \mathrm{~min}$ at $60^{\circ} \mathrm{C}$ in the case of Type II

104 methanotrophs. The limit of detection for the qPCR assays was estimated to be 30 copies

105 per reaction for Type I, 50 copies per reaction for Type II, 200 copies per reaction for

106 OPU1, and 56 copies per reaction for OPU3. All the results were standardized to the

107 volume (per $\mathrm{mL}$ ) of seawater the DNA was extracted from.

109 Enumeration of pmoA phylotypes was performed in an ABI 7300 real time PCR system

110 with the following conditions. The OPU3 pmoA phylotype was performed using primers,

111 Taqman probe, and conditions as previously reported ${ }^{42}$. Primers and Taqman probe

112 specific to the OPU1 pmoA phylotype (primers pmoA_OPU1qPCR_242f: 5'-

113 TTACCCCGATCATGCTGGTT-3' and pmoA_OPU1qPCR_312r: 5'-

114 GATTCTGAAGTGTTCCCAAACGA-3'. Probe: 5'-TTCCCAGCCGCTGTTCAGGCA-

$1153^{\prime}$ ') and primers specific to the novel $p m o A$ phylotype (primers $p m o A_{-}$spill_f: 5'- 
116 AAACTATGAGTTTAACTGCTG-3' and pmoA_spill_r: 5'-

117 TCAAAATTCCGCACAATCTTT-3’) were developed using Primer Express v 2.0.

118 OPU1 enumeration was performed using cycling conditions as reported previously for

119 the OPU3 pmoA phylotype. To enumerate the novel phylotype, a SYBR assay (Power

120 SYBR green, Applied Biosystems) was developed. $1 \mu 1$ each of template DNA, forward

121 and reverse primer $(0.5 \mu \mathrm{M}$ final concentration), and water were added to a final volume

122 of $20 \mu 1$. qPCR was performed with a $95^{\circ} \mathrm{C}$ denaturation for $10 \mathrm{~min}$, followed by 40

123 cycles of $95^{\circ} \mathrm{C}\left(15^{\prime \prime}\right)$ and an extension at $58^{\circ} \mathrm{C}\left(1^{\prime}\right)$. A final dissociation curve was

124 included. For all functional gene assays, $\mathrm{CsCl}$-purified linearized plasmid DNA was used

125 as a standard. Primers displayed $>95 \%$ amplification efficiency as measured over five

126 orders magnitude and cross reactivity between target templates was below detection.

127 Limit of detection for $p m o A$ qPCR assays was 10 copies per reaction. The results were

128 standardized to the $\mathrm{mL}$ of seawater.

130 Statistics:

131 A Wilcoxon Test was performed using Kaleidagraph (version 4.1) to determine the

132 significance of the changes observed in qPCR results over the time.

133

134 Clone libraries, sequencing, and phylogenetic analysis:

135 pmoA gene fragments were amplified by polymerase chain reaction (PCR) from DNA

136 obtained form eleven samples representing different time points and locations during our

137 sampling campaign (Supplementary Table S2) using primer set wcpmoA189f and

138 wcpmoA661 $\mathrm{r}^{43}$. The PCR protocol consisted of an initial denaturation of 3 min at $94^{\circ} \mathrm{C}$, 
139 followed by $28-40$ cycles of 1 min at $94{ }^{\circ} \mathrm{C}, 30$ s at $56^{\circ} \mathrm{C}$, and 45 s at $72^{\circ} \mathrm{C}$, ending with a

140 final extension of $5 \mathrm{~min}$ at $72{ }^{\circ} \mathrm{C}$. The PCR master mix consisted of of $1-20 \mathrm{ng} / \mu 1 \mathrm{DNA}$

141 and either 1X GoTaq Flexi Reaction Buffer, $1.25 \mathrm{u}$ of GoTaq Flexi DNA Polymerase

142 (Promega Corporation, Madison, WI), $2.5 \mathrm{mM} \mathrm{MgCl}_{2}, 0.25 \mathrm{mg} / \mathrm{ml} \mathrm{BSA}, 100 \mu \mathrm{M}$ dNTP

$143 \mathrm{mix}, 1 \mu \mathrm{M}$ of each primer, and $\mathrm{ddH}_{2} \mathrm{O}$ to a final volume of $25 \mu \mathrm{l}$; or OmniTaq DNA

144 polymerase $(0.5 \mu \mathrm{L}), 1 \mathrm{X}$ Omni Taq reaction buffer, $100 \mu \mathrm{M}$ dNTP mix, $1 \mu \mathrm{M}$ of each

145 primer and $\mathrm{ddH}_{2} \mathrm{O}$ to a final volume of $25 \mu \mathrm{l}$.

146 Amplified pmoA gene fragments were gel-purified using the QIAGEN Qiaquick

147 gel extraction kit (Qiagen, Santa Clarita, CA, USA), and cloned into a pCR4-TOPO

148 plasmid vector (Invitrogen, Inc., Carlsbad, CA, USA) at a 1:3 vector to insert ratio. The

149 ligation products were transformed into E. coli One Shot Top10 competent cells

150 (Invitrogen, Inc., Carlsbad, CA, USA). Ampicillin resistant clones were selected and

151 grown up overnight at $37^{\circ} \mathrm{C}$ in freezing medium (LB $+100 \mu \mathrm{g} / \mathrm{ml} \mathrm{Amp}+10 \%$ glycerol).

152 One $\mathrm{mL}$ of the clones was spun down and cell pellets were sent to Laragen, Inc (Culver

153 City, CA) for Sanger sequencing. Sequences were also screened for closest relatives

154 using the blastn application of the NCBI database. Sequences were aligned using Clustal

$155 \mathrm{X}$ version 2.1 and manually adjusted using Seaview ${ }^{44}$. Operational taxonomic units

156 (OTUs) were defined as sequences sharing more than 97\% similarity and were calculated

157 using MOTHUR ${ }^{45}$.

158 Sequences were translated using the online tool EMBOSS Transeq

159 (http://www.ebi.ac.uk/emboss/transeq/). The amino acid sequences were aligned with

160 Clustal X version 2.1 and manually adjusted using Seaview ${ }^{44}$. Phylogenetic distances

161 were calculated using the Observed Divergence matrix, and the neighbor joining method 
162 was used to evaluate tree topologies. Phylo_win version 2.0 was utilized to plot tree

163 topologies ${ }^{44}$ whose robustness was tested by bootstrap analysis (1000 resamplings).

165 Supplementary Discussion

166 Evidence that Macondo Methane was Dispersed through the Water Column after June

1672010 :

168 The methane present in the water column at MC118 in June 2010 was distinct from the

169 thermogenic methane that typifies the MC118 site (Bowles et al. 2011, Geochimica et

170 Cosmochimica Acta). The mid-water methane concentration measured at MC118 in June

1712010 had a d ${ }^{13} \mathrm{C}-\mathrm{CH}_{4}$ of $-53.8 \pm 1.5 \%$ ( $\left.=5\right)$ and was as depleted as $-55 \%$, which is

172 significantly lighter than the average $\mathrm{d}^{13} \mathrm{C}-\mathrm{CH}_{4}$ signature of methane at MC118 (-45\%)

173 and outside the bounds of the range noted by the reviewer (-48 to $-52 \%$ ). We have made

174 nearly 100 measurements of methane concentration and isotopic composition in the water

175 column above MC118 since 2010. Typically, methane concentrations are maximal near

176 the seafloor and decrease with distance above the bottom. The concentrations measured

177 in June 2010 were low except for the anomalous high concentration zone present in the

178 mid-water; so we conclude that this methane was Macondo in origin.

179

180 Furthermore, other stations north of MC252, and east/northeast from MC118 also

181 exhibited methane concentration $>100 \mathrm{nM}$ after July 2010. For example, we observed a

182 methane concentration of $109 \mathrm{nM}$ at $750 \mathrm{~m}$ at Cape Hatteras Station $68(29.04,-88.12)$.

183 This station is located $23 \mathrm{~nm}$ from MC252, which lead us to conclude that deepwater

184 plume methane was dispersed upwards through the water column in a broad fashion. 
185 Other examples of stations east/northeast of MC252 that exhibited methane

186 concentrations $>100 \mathrm{nM}$ are presented in a table on the following page. 


\begin{tabular}{|c|c|c|c|c|c|c|c|}
\hline \multirow[b]{3}{*}{ Site/ } & \multirow[b]{4}{*}{ Date } & \multirow[b]{4}{*}{ Lat } & \multirow[b]{4}{*}{ Long } & \multirow{2}{*}{$\begin{array}{l}\text { Distance to } \\
\text { MC252 }\end{array}$} & \multicolumn{2}{|l|}{ Heading } & \multirow[t]{2}{*}{189} \\
\hline & & & & & from & & \\
\hline & & & & (nautical & $\mathrm{MC} 252$ & Depth & Methane \\
\hline Station & & & & miles) & (degrees) & (m) & $(\mathrm{nM})$ \\
\hline $\mathrm{CH} 065$ & 11 Sept 2010 & 28.71 & -87.93 & 24 & 94 & 309 & 138 \\
\hline CH066 & 12 Sept 2010 & 28.88 & -87.93 & 26 & 70 & 719 & 132 \\
\hline CH066 & 12 Sept 2010 & 28.88 & -87.93 & 26 & 70 & 567 & 157. \\
\hline $\mathrm{CH} 066$ & 12 Sept 2010 & 28.88 & -87.93 & 26 & 70 & 444 & 125 \\
\hline CH067 & 12 Sept 2010 & 29.04 & -87.93 & 30 & 52 & 51 & 143 \\
\hline CH068 & 12 Sept 2010 & 29.04 & -88.12 & 23 & 37 & 750 & 109 \\
\hline $\mathrm{CH} 076$ & 13 Sept 2010 & 29.24 & -88.01 & 35 & 33 & 68 & 174 \\
\hline $\mathrm{CH} 077$ & 13 Sept 2010 & 29.23 & -87.82 & 42 & 44 & 212 & 125 \\
\hline $\mathrm{CH} 077$ & 13 Sept 2010 & 29.23 & -87.82 & 42 & 44 & 186 & 141 \\
\hline
\end{tabular}


191 All of the data presented in this paper are available electronically through the Gulf of

192 Mexico Research Initiative's Data Warehouse (https://data.gulfresearchinitiative.org/).

193

194

195

196

197

198

199

200

201

202

203

204

205

206

207

$208 \quad 36$

209

210

211

212

213

$214 \quad 38$

215

216

\section{Supplementary References}

31 Joye, S. B., MacDonald, I. R., Leifer, I. \& Asper, V. Magnitude and oxidation potential of hydrocarbon gases released from the BP oil well blowout. Nat. Geosci. 4, 160-164 (2011).

32 Schmitt, M., Faber, E., Botz, R. \& Stoffers, P. Extraction of methane from seawater using ultrasonic vacuum degassing. Anal. Chem. 63, 529-532 (1991).

33 Carini, S., Bano, N., LeCleir, G. \& Joye, S. B. Aerobic methane oxidation and methanotroph community composition during seasonal stratification in Mono Lake, California (USA). Environ. Microbiol. 7, 1127-1138 (2005).

34 Sandbeck, K. A. \& Reeburgh, W. S. Microbiological preparation of H-3-labeled methane. J. Labelled Compd. Rad. 27, 1285-1291 (1989).

35 Chanton, J. \& Liptay, K. Seasonal variation in methane oxidation in a landfill cover soil as determined by an in situ stable isotope technique. Global.

Biogeochem. Cy. 14, 51-60 (2000).

36 Joye, S. B. et al. The anaerobic oxidation of methane and sulfate reduction in sediments from Gulf of Mexico cold seeps. Chem. Geol. 205, 219-238, doi:Doi 10.1016/J.Chemgeo.2003.12.019 (2004).

37 Shiller, A. M. Syringe filtration methods for examining dissolved and colloidal trace element distributions in remote field locations. Environ. Sci. Technol. 37, 3953-3957 (2003).

38 Wu, J. F. \& Boyle, E. A. Low blank preconcentration technique for the determination of lead, copper, and cadmium in small-volume seawater samples by isotope dilution ICPMS. Anal. Chem. 69, 2464-2470 (1997). 
39 Vetriani, C., Jannasch, H. W., MacGregor, B. J., Stahl, D. A. \& Reysenbach, A-L. Population structure and phylogenetic characterization of marine benthic archaea in deep-sea sediments. Appl. Environ. Microbiol. 65, 4375-4384 (1999). Adams, M. M., Hoarfrost, A. L., Bose, A., Joye, S. B. \& Girguis, P. R. Anaerobic oxidation of short-chain alkanes in hydrothermal sediments: potential influences on sulfur cycling and microbial diversity. Front. Microbiol. 4, 110, doi:10.3389/fmicb.2013.00110 (2013).

41 Tavormina, P. L., Ussler, W., 3rd, Joye, S. B., Harrison, B. K. \& Orphan, V. J. Distributions of putative aerobic methanotrophs in diverse pelagic marine environments. ISME J 4, 700-710 (2010).

42 Tavormina, P. L., Ussler, W.3rd, Steele, J. A., Connon, S. A., Klotz, M. G., \& Orphan, V. Abundance and distribution of diverse membrane-bound monooxygenase ( $\mathrm{Cu}-\mathrm{MMO})$ genes within the Costa Rica oxygen minimum zone. Environ. Microbiol. Rep. 5(3), 414-423 (2013).

43 Tavormina, P. L., Ussler, W., $3^{\text {rd }}$, \& Orphan, V. J. Planktonic and sedimentassociated aerobic methanotrophs in two seep systems along the North American Margin. Appl. Environ. Microbiol. 74 (13), 3985-3995 (2008).

44 Galtier N, Gouy M, Gautier C. (1996). SEAVIEW and PHYLO_WIN: Two graphic tools for sequence alignment and molecular phylogeny. Comput. Appl. Biosci. 12(6): 543-548.

45 Schloss PD, Westcott SL, Ryabin T, Hall JR, Hartmann M, Hollister EB, et al. (2009). Introducing mothur: open-source, platform-independent, communitysupported software for describing and comparing microbial communities. Appl. Environ. Microbiol. 75(23): 7537-7541. 


\section{Captions for Supplementary Figures}

248 Supplementary Fig. 1. Map showing the study sites over space and time. The

249 sampling sites as a function of time since the Deepwater Horizon exploded are shown

250 (colour code denotes time). The star denotes the location of the Macondo wellhead.

251

252 Supplementary Fig. 2. Average methane concentration over 50-day periods.

253 Maximum methane concentrations over time, binned in 200m depth and 50 day intervals

254 (colour coding is the same as Fig. 1) illustrating dispersion of the deep-water plume over 255 time.

256

257 Supplementary Fig. 3. Dissolved alkane concentrations in the water column during 258 May and June 2010. Concentration of $\mathrm{C}_{2}-\mathrm{C}_{5}$ alkanes (time colouring extends to day 50 259 only as concentrations were below detection after that time; colour coding same as Figs. 2601.

261

262 Supplementary Fig. 4. Dissolved nutrient concentrations in the water column over

263 the 10-month time-course. Concentration of ammonium, nitrate+nitrite, and phosphate 264 over depth (all concentrations are in $\mu \mathrm{M}$ ) for the various study sites are shown. 
Supplementary Table 1.

\begin{tabular}{|c|c|c|c|c|c|c|c|c|}
\hline Date & $\begin{array}{l}\text { Research } \\
\text { Vessel }\end{array}$ & $\begin{array}{c}\text { Site/ } \\
\text { Station }\end{array}$ & Lat & Long & ID & $\begin{array}{l}\text { Depth } \\
\text { (m) }\end{array}$ & $\begin{array}{c}\text { Extraction } \\
\text { Method }\end{array}$ & Remarks \\
\hline 12-May-10 & \multirow[t]{2}{*}{ Pelican } & Site_39 & 28.70 & -88.39 & WC45 & 1265 & MoBio Kit & \multirow[t]{2}{*}{$\begin{array}{c}\text { Combined } \\
\text { DNA }\end{array}$} \\
\hline 14-May-10 & & Site_33A & 28.72 & -88.42 & WC75 & 1220 & MoBio Kit & \\
\hline 14-May-10 & Pelican & Site_34A & 28.71 & -88.39 & WC65 & 1020 & MoBio Kit & $\begin{array}{c}\text { Individual } \\
\text { sample }\end{array}$ \\
\hline 26-May-10 & \multirow[t]{2}{*}{$\begin{array}{l}\text { Walton } \\
\text { Smith }\end{array}$} & WS2 & 28.73 & -88.41 & C4-9 & 1120 & MoBio Kit & \multirow[t]{2}{*}{$\begin{array}{c}\text { Combined } \\
\text { DNA }\end{array}$} \\
\hline 4-Jun-10 & & WS6 & 28.74 & -88.38 & C73-3 & 1180 & MoBio Kit & \\
\hline 30-May-10 & $\begin{array}{l}\text { Walton } \\
\text { Smith }\end{array}$ & WS36 & 28.71 & -88.41 & C40-6 & 1220 & $\begin{array}{l}\text { Vetriani et } \\
\text { at., } 1999\end{array}$ & $\begin{array}{c}\text { Individual } \\
\text { sample }\end{array}$ \\
\hline $1-J u n-10$ & $\begin{array}{l}\text { Walton } \\
\text { Smith }\end{array}$ & WS53 & 28.73 & -88.38 & C59-3 & 1170 & $\begin{array}{l}\text { Adams et } \\
\text { al., } 2013\end{array}$ & $\begin{array}{c}\text { Individual } \\
\text { sample }\end{array}$ \\
\hline 9-Sep-10 & Oceanus & 022.01 & 29.00 & -88.80 & 179 & 162 & MoBio Kit & $\begin{array}{c}\text { Individual } \\
\text { sample }\end{array}$ \\
\hline 30-Aug-10 & Oceanus & 014.02 & 27.37 & -90.56 & 101 & 1222 & MoBio Kit & $\begin{array}{c}\text { Individual } \\
\text { sample }\end{array}$ \\
\hline 30-Aug-10 & Oceanus & 014.02 & 27.37 & -90.56 & 102 & 1000 & MoBio Kit & $\begin{array}{c}\text { Individual } \\
\text { sample }\end{array}$ \\
\hline 30-Aug-10 & Oceanus & 014.02 & 27.37 & -90.56 & 103 & 700 & MoBio Kit & $\begin{array}{c}\text { Individual } \\
\text { sample }\end{array}$ \\
\hline 13-Sep-10 & Oceanus & 027.11 & 28.55 & -88.32 & 242 & 1289 & MoBio Kit & $\begin{array}{c}\text { Individual } \\
\text { sample }\end{array}$ \\
\hline
\end{tabular}


$\mathrm{CH}_{4}(\mathrm{nM})$, binned

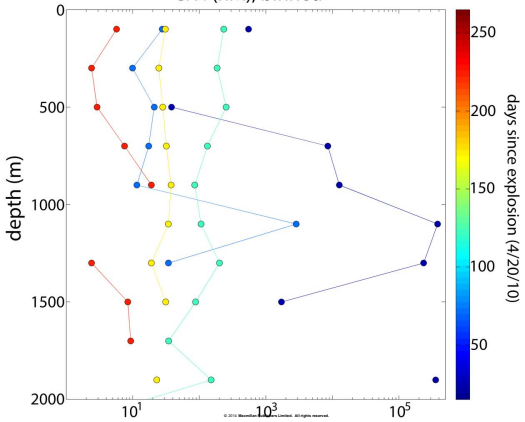




\section{concentration (nM)}

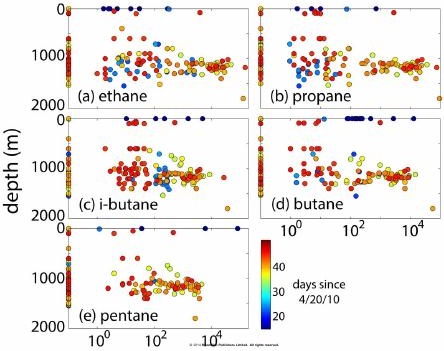




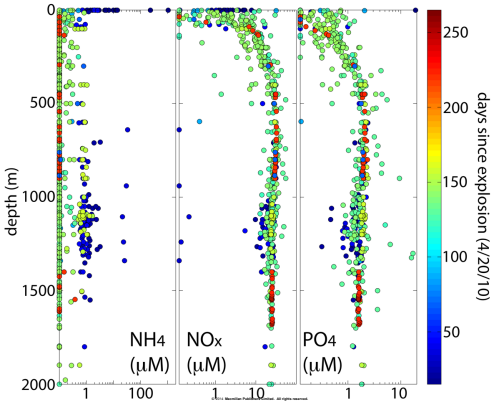

